\title{
肺癌患者の免疫スペクトルの検討 NK活性とDNCB反応の組合わせについて
}

\author{
The Immune Spectrum in Patients with Lung Cancer
}

北村 曠・三上理一郎・坂口泰弘・米田尚弘

堅田 均・前川純子・西川 潔・成田亘啓

要旨：肺癌未治療患者58例について, NK活性とDNCB反応を検索し, 両者の組合わせによる免 疫スペクトルを 4 群に分け, 免疫能と臨床病態との関係を検討した。A群は一般状態 （PS）が良好で，遠隔転移が少なく，82\%の高率で治療が期待できるが，BないしC群，D 群と免疫能の低下に伴って, PSの悪化と病期の進展がみられ, D群は全例治療不可能で あった。この新しい免疫スペクトルは, 患者の予後の推則と治療方針の決定に有用であ る.

〔肺癌 26(4) : 403 409, 1986〕

Key words : Natural killer cell activity, DNCB skin reaction, Immune spectrum of lung cancer.

\section{緒 言}

担癌生体では，細胞性免疫を主体とする免疫 監視機構が, 臨床病態や病期の進展に深く関与 している。これら宿主の免疫能を, いかなる指 標で把握するのがよいかについて, 多くの報告 がなされている!) 5),16) 18)著者らは, 肺癌患者の 免疫能と臨床病態との関係を, 広範囲にかつ具 体的に明確化するため, 腫痬免疫監視機構に重 要な役割をはたしているNatural killer細胞活 性と, DNCB (2, 4-dinitrochlorobenzen) 皮膚反 応の両者を同時に測定した，そして，両者の組 合わせによる免疫スペクトルを作成し, 一般状 態 (performance status), 臨床病期, 治療との 関係について検討し，有意義な知見を得たので 報告する。

\section{対象及び方法}

昭和 58 年 9 月から 59 年 10 月までに，当科に入

奈良県立医科大学第 2 内科
院した肺癌未治療患者58例(男48例，女10例)を 対象とした。年令は51才から81才，平均 65.8 才 であった，日本肺癌学会臨床病期分類では，I 期 5 例，II 期 5 例，III期24例，IV 期24例で， Zubrodの基準 ${ }^{6)}$ にる performance status(PS)の 分類では, PS 0 ；6 例, PS 1 ；23例, PS $2 ； 15$ 例, PS $3 ； 4$ 例, PS 4 ；10例であった. 組織型 別では，扁平上皮癌 24 例，腺癌 18 例，小細胞癌 11例, 大細胞癌 4 例, 腺扁平上皮癌 1 例である. NK活性とDNCB反応のコントロールとして， それぞれ別の対照群より40例と34例の，身体的 血清学的に異常を認めない健常人を検討した。

\section{NK活性の測定}

へパリン加末梢血約 $10 \mathrm{ml}$, phosphate-buffered saline(PBS)にて 2 倍希釈し, FicollConray比重遠沈法にて単核球を分離採取した。 さらにPBSにて 3 回洗浄後，培養液 $10 \%$ fetal calf serum (FCS)加RPMI1640にて, $4 \times 10^{6} /$ $\mathrm{ml}$ に調整した。その $100 \mu \mathrm{l}$ を microplate のwell 
に入れ, effectorの細胞とした. target細胞は, ヒト白血病細胞由来培養株K562を用いた。 これ を $6 \times 10^{6} / 100 \mu 1$ とし, $100 \mu \mathrm{Ci} の \mathrm{Na}_{2}{ }^{51} \mathrm{CrO}_{4}$ を添 加, $37^{\circ} \mathrm{C} 1$ 時間incubateし, ${ }^{51} \mathrm{Cr}$ の標識を行っ た.その後 3 回洗浄し, $2 \times 10^{4} / 100 \mu 1$ をeffector 細胞に加えた $\left(\mathrm{E} / \mathrm{T}\right.$ ratio=20)，5\% $\mathrm{CO}_{2}$ incubatorにて, $37^{\circ} \mathrm{C} 4$ 時間incubation後, 遠沈し その上清中の放出 ${ }^{51} \mathrm{Cr}$ 量を $\boldsymbol{\gamma}$-counterにて測定 した.\% natural killer (NK) cell activityは次式 にて算出した。

$\% \mathrm{NK}$ cell activity

$=\frac{\text { experimental release }- \text { spontaneous release }}{\text { maximum release }- \text { spontaneous release }} \times 100$

spontaneous releaseは, effector細胞を加之 ないで自然に放出される ${ }^{51} \mathrm{Cr}$ 量である， maximum releaseは, ${ }^{51} \mathrm{Cr}$ 標識したtarget細胞に $1 \mathrm{~N} \mathrm{HCl}$ 加えて, 最大限に放出される ${ }^{51} \mathrm{Cr}$ 量 である. spontaneous releaseは, maximum releaseの $10 \%$ 以下であった. また, 各測定ごと に同一健常人 2 名を同時に測定し, NK活性值 の補正を行った。

\section{DNCB皮庙反応の測定}

$1 \% \mathrm{DNCB}$ アトン溶液 $0.025 \mathrm{ml}(250 \mu \mathrm{g})$ を パッチテスト用䋖創高に滴下し，感作用とした。 同様に，0.1\%DNCBアセトン溶液 $0.05 \mathrm{ml}$ (50 $\mu \mathrm{g})$ を滴下したものを判定用とした。感作用絆 創高を左上腕に 24 時間貼付し, 14 日後, 判定用 を右上腕に 48 時間貼付，反応をみた。

判定基準は，（一：反応なし，（士）: 部分的 発赤, (+)：硬結のない紅斑, (H)：硬結を伴 j紅斑, (卅) $:$ 水泡形成, (卅) : 大水疮や壊死, と 6 段階に分けた。

そして，（+）以下を反応低下，（） 以上を反 応正常とした.

\section{結 奥}

I 、健常人および肺癌患者のNK活性とDNCB反 応 (Table 1)

健常人の NK 活性の平均值は, $42 \pm 17 \%$ (25～59\%)であった．年令別平均では，50才未 満 $41 \pm 17 \%(n=24), 50$ オ上 $44 \pm 16 \%(n=$ 16)で，年令による差は認められなかった。肺癌
Table 1. NK activity and DNCB skin reaction in normal controls and lung cancer patients

\begin{tabular}{|c|c|c|c|c|}
\hline Group & No.tested & $\begin{array}{c}\text { Mean age } \\
\text { (range) }\end{array}$ & NK activity & $\begin{array}{c}\% \text { negative } \\
\text { DNCB }\end{array}$ \\
\hline \multirow[t]{4}{*}{ Normal control } & 40 & $43.7(22 \sim 84)$ & $42 \pm 17 \%^{*}$ & \\
\hline & 24 & $33.2(22 \sim 49)$ & $41 \pm 17 \%$ & \\
\hline & 16 & $64.4(50 \sim 84)$ & $44 \pm 16 \%$ & \\
\hline & 34 & $62.3(45 \sim 86)$ & & $15 \% \%^{* *}$ \\
\hline Lung cancer & 58 & $65.8(51 \sim 81)$ & $33 \pm 17 \%^{*}$ & $60 \%{ }^{* *}$ \\
\hline
\end{tabular}

Table 2. Correlation between NK activity and DNCB skin reaction in patients with lung cancer

\begin{tabular}{ccl}
\hline DNCB & No. of patients & NK activity \\
\hline positive & 23 & $36 \pm 17 \% *$ \\
negative & 35 & $32 \pm 17 \% *$ \\
\hline & & $*$ N.S.
\end{tabular}

患者全体のNK活性平均値は, $33 \pm 17 \%$ で健常 人にくらべ有意に低下していた $(\mathrm{P}<0.05)$.

また，肺癌患者全体のDNCB反応低下率は60 \%で，年令をほぼマッチさせた健常人の低下率 15\%にくらべ, 有意に低下していた $(\mathrm{P}<0.01)$. 2. NK活性とDNCB反応の相関 (Table 2)

肺癌患者における DNCB反応正常者23例の NK活性は $36 \pm 17 \%$ で，反応低下者 35 例のNK活 性は $32 \pm 17 \%$ であり, DNCB反応正常者群と低 下者群の間では，NK活性に差はなかった。

\section{3.免疫スペクトルと臨床病態}

NK活性とDNCB反応の 2 つの指標を用いて， 免疫スペクトルの作成を試み，4群に分類した。 NK活性は, 健常対照群の平均值 $42 \pm 17 \%$ (25 59\%)の下限を基準にし，25\%以上を反応 正常，25\%未満を反応低下とした.

これより，A群：NK活性25\%以上でDNCB 反応正常, B 群 : NK活性 $25 \%$ 以上でDNCB反 応低下, C 群 : NK活性25\%未満でDNCB反応 正常, D群：NK活性 $25 \%$ 未満でDNCB反応低 下の 4 群に分類した。肺㿋患者 4 群の内訳は, $\mathrm{A}$ 群17例, B群19例, C群 6 例, D群16例であ った。 
Table 3. Relationship between the immune spectrum and clinical status

\begin{tabular}{|c|c|c|c|c|c|}
\hline \multicolumn{6}{|l|}{ Immune spectrum } \\
\hline NK & & $\geqq 25 \%$ & $\geqq 25 \%$ & $<25 \%$ & $<25 \%$ \\
\hline DNCB & & positive & negative & positive & negative \\
\hline (No. of patients) & & $(n=17)$ & $(n=19)$ & $(n=6)$ & $(n=16)$ \\
\hline \multicolumn{6}{|l|}{ Clinical status } \\
\hline \multirow[t]{3}{*}{ PS } & $0-1$ & 15 & 8 & 4 & 2 \\
\hline & $2-3$ & 2 & 9 & 2 & 6 \\
\hline & 4 & 0 & 2 & 0 & 8 \\
\hline \multirow[t]{3}{*}{ Clinical stage } & $I-\mathbb{I}$ & 6 & 3 & 1 & 0 \\
\hline & III & 6 & 11 & 3 & 4 \\
\hline & N & 5 & 5 & 2 & 12 \\
\hline
\end{tabular}

PS = performance status (Zubrod)

以上の免疫スペクトルを用いて，臨床病態と の関係を検討した (Table 3).

1) 免疫スペクトルとPS

PSとの関係では, A 群は 17 例中 15 例が, PS 0 ないし 1 であるが，D群では16例中14例がPS 2 以上の就床を必要とする状態であった。 Bない しC群では, その中間の成績が示された。

\section{2 ) 免疫スペクトルと臨床病期}

臨床病期との関係では，A群は17例中 I ・ II 期が 6 例, III期 6 例, IV 期 5 例であるが, B 群 ないし C 群, D群になるにつれて臨床病期が進 んだ例が多くなり，D群では16例中 I ・ II 期は なく，III期 4 例， IV 期12例であった.

\section{4.免疫スペクトルと治療}

はじめに, 治療との関係をNK活性単独で検 討すると (Table 4左側), $25 \%$ 以上の反応正常者 は, 36例中 24 例 $(67 \%)$ が, 治癒手術・準治癒手 術可能症例や, 放射線 - 化学療法併用療法に対 Lcomplete response $(\mathrm{CR}) \cdot$ partial response (PR)を示した治療奏効例であるが, $25 \%$ 未満の 反応低下者は，22例中19例 (86\%) がNo Change (NC) - progressive disease (PD) 症例や, 重篤 な合併症や副作用のため, 治療を途中で中止せ ざるをえない効果判定不能例 $(\mathrm{NE}) や ， 一$ 般状 態が悪く最初から治療対象外の症例 $(\mathrm{NT})$ であ った.

同様に, DNCB反応単独で検討すると (Table 4右側), 反応正常者は，23例中17例 (74\%)に治 療効果が認められたが, 反応低下者では，35例
Table 4. Relationship between the immune parameters and treatment status

\begin{tabular}{|c|c|c|c|c|}
\hline \multirow[t]{2}{*}{ Immune parameter } & \multicolumn{2}{|c|}{ NK } & \multicolumn{2}{|c|}{ DNCB } \\
\hline & $\begin{array}{c}\text { normal } \\
\geqq 25 \%)\end{array}$ & $\begin{array}{c}\text { subnormal } \\
(<25)\end{array}$ & positive & negative \\
\hline \multicolumn{5}{|l|}{ Treatment status } \\
\hline Operable & 8 & 1 & 7 & 2 \\
\hline$C R \cdot P R$ & $\frac{16}{24 / 36(67 \%)}$ & $\frac{2}{3} / 22(14 \%)$ & $\frac{10}{17 / 23(74 \%)}$ & $\frac{8}{10 / 35(29 \%)}$ \\
\hline$N C \cdot P D$ & 7 & 3 & 2 & 8 \\
\hline NE & 4 & 7 & 3 & 8 \\
\hline NT & $\frac{1}{12 / 36(33 \%)}$ & $\frac{9}{19 / 22(86 \%)}$ & $\frac{1}{6 / 23(26 \%)}$ & $\frac{9}{25 / 35(71 \%)}$ \\
\hline
\end{tabular}

CR=complete response ; $P R=$ partial response ; $N C=$ no change ; $\mathrm{PD}=$ progressive disease ;

$N E=$ not evaluable because of serious complications or side effects : NT = not treated because of poor performance status.

Table 5. Relationship between the immune spectrum and treatment status

\begin{tabular}{|c|c|c|c|c|}
\hline Immune spectrum & group A & group B & group C & group D \\
\hline NK & $\geqq 25 \%$ & $\geqq 25 \%$ & $<25 \%$ & $<25 \%$ \\
\hline DNCB & positive & negative & positive & negative \\
\hline (No. of patients) & $(n=17)$ & $(n=19)$ & $(n=6)$ & $(n=16)$ \\
\hline \multicolumn{5}{|l|}{ Treatment status } \\
\hline Operable & 6 & 2 & 1 & 0 \\
\hline$C R \cdot P R$ & $\frac{8}{14 / 17(82 \%)}$ & $\frac{8}{10 / 19(53 \%)}$ & $\frac{2}{3 / 6(50 \%)}$ & $\frac{0}{0 / 16(0 \%)}$ \\
\hline$N C \cdot P D$ & 2 & 5 & 0 & 3 \\
\hline NE & 1 & 3 & 2 & 5 \\
\hline NT & $\frac{0}{3 / 17(18 \%)}$ & $\frac{1}{9 / 19(47 \%)}$ & $\frac{1}{3 / 6(50 \%)}$ & $\frac{8}{16 / 16(100 \%)}$ \\
\hline
\end{tabular}

中25例 $(71 \%)$ が, 治療無効ないし不可能な症例 であった。

次に, 両者の組合わせによる免疫スペクトル で検討すると (Table 5), 治療効果が認められた 者は，A群は17例中14例 (82\%)で最も高率であ るが, B群では19例中10例 (53\%), C群では 6 例中 3 例 (50\%) と低下していた。 そしてD群で は, 16例全例 (100\%) が治療無効ないし不可能な 症例であった。

肺癌患者の免疫能の指標として, NK活性と DNCB反応を個々に用い, 臨床病態との関係を 検討した報告は多い(1) 3),55,(16) 199著者らの成績で も多くの報告者と同様に, NK活性と DNCB反 応は健常者にくらべ, それぞれ有意に低下して いた。 
NK細胞は，腫瘍に対する生体側防禦の第一 線にある細胞と考えられている，担癌生体にお けるNK活性低下の原因として, NK細胞に対す

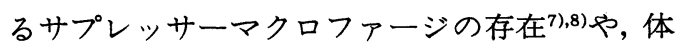
液性免疫抑制因子9 ${ }^{911}$ が報告されている。しか し，その詳細な機序に関しては，必ずしも明確 でない. Liberatiら ${ }^{12)}$ は，NK活性は腫唄の進展 とともに低下するが，NK活性単独で治療前に 予後を予測することはできないと述べている.

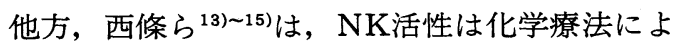
り著明に低下するが, 治療奏効例では, その後 もとの值に回復するとし, NK活性の変動と治 療との関係を明らかにしている。

DNCB反応は, 遅延型免疫皮膚反応で, 感作 の導入から反応の成立まで, 宿主の免疫応答細 胞や液性因子等の多くの機能が反映されている. 従って, 本反応はin vivoでの細胞性免疫能を知 る目的で, 多くの腫瘍患者に応用され，患者の 病態や予後のよい指標とされている5),16) 18) し かし, 高令者では新しい抗原に対する反応性が 低下するという報告19),20)もあり，担癌による反 応低下以外の要素も考慮しなければならない。

Golubら (1974年) ${ }^{21}$ は, 種々の悪性腫瘍を対 象としてリンパ球幼若化反応や, 混合リンパ球 培養試験 $(\mathrm{MLC})$ と, DNCB反応などとの相関を 検討し, in vitro検查と in vivo検查の組合わせ は, 担癌生体の免疫能をより広範囲に, かつ具 体的に評価するのに有用であると発表している。 著者らが, 肺癌患者で検索した NK活性と $\mathrm{DNCB}$ 反応の相関をみた場合, DNCB反応低下 例でも，反応正常例にくらべNK活性は低下し ておらず，両者間に相関関係はみられなかった。 したがって，この 2 つの検査は，それぞれ異な つたタイプの免疫能を反映している指標である と思われる。すなわち, NK活性は前感作の操作 なしに，自然に備った腫瘍細胞障害性反応であ $\eta, \mathrm{DNCB}$ 反応は, 新しい抗原の感作による認 識と応答という生体の細胞性免疫能の反映であ る.

Lenziniら (1977年) ${ }^{22)}$ は, 結核患者における臨 床病態の多様性を, 異なった夕イプの免疫因子 の組合わせにより分類した。すなおち，PPD反
応や白血球遊走阻止試験による細胞性免疫能と, 抗PPD抗体の測定による体液性免疫能の組合 わせを, 反応性と非反応性という両極端のグル 一プと, さらにその中間の 2 群を加えて 4 群の 免疫スペクトルに分類し, 臨床病理像, 抗結核 薬に対する反応性との対応を示し, 結核患者に おける免疫応答能のスペクトルの概念を提唱し た。

三上 ${ }^{23)} \cdot$ 米田 ${ }^{24)}$ は, 難治性肺結核患者29例 を, DNCB反応と NK活性值より, 高反応群 8 例, 中間型反応群 13 例, 低反応群 8 例と分け, 高反応群は低反応群にくらべ, 良好な臨床経過 をとることを示し, 免疫スペクトルの有用性を 認めている。

担癌患者では, 種々の免疫学的因子は, 診断 よりもむしろその病態を知り, 治療効果や予後 を予測するのに役立てられている(1) 5),16) 18),25) 28). 今回, 著者らは上述のLenziniらのヒト結核の免 疫スペクトルの考え方を, 肺癌患者の病態と治 療・予後の把握に応用しようと試みた。すなわ ち, NK活性とDNCB反応の両方が正常な群を一 方の極の A 群とし, 反対に両反応とも低下して

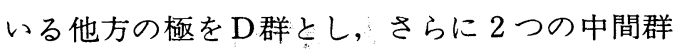
$\mathrm{B}, \mathrm{C}$ 群を加之， 4 群によって肺癌患者の免疫 スペクトルを作成した。この免疫スペクトルは, 臨床病態や治療とよく相関する事が示された。 すなわち，A群は臨床病態が良好で，手術又は 放射線・化学療法による治療が高率に期待でき, 他方 $\mathrm{D}$ 群は病態が悪化し, 全例に治療が期待で きず， B・C 群はその中間の成績を呈し，この スペクトルが連続的に移行していくことが認め られた。

この著者らが試みた新しい免疫スペクトルに よる肺癌患者の分類は, 従来の単一の指標の場 合と比較して, 患者の病態や予後の把握により 有用である。すなわち，NK活性正常例36例は， 67\%に治療が期待でき, DNCB反応正常例 23 例 は， $74 \%$ に治療が期待できるが，两反応を組合 わせた免疫スペクトルでみると, 再反応とも正 常な $\mathrm{A}$ 群17例は， $82 \%$ と単独の場合よりも高率 に治療が期待できる.

また, 反応低下例についてみると, NK活性低 
下 22 例の $86 \%$, DNCB反応低下 35 例の $71 \%$ が治 療が期待できないのに対して，免疫スペクトル による両反応がともに低下しているD群では, 16例全例 $100 \%$ が治療が期待できなかった。

今日，外科治療を除いた内科的治療からみた 場合, 肺癌患者の治療・予後はきわめて悲観的 であり，患者の馀療がきわめてむずかしい。こ の様な現状において, 今回とりあげたNK活性 とDNCB反応による免疫スペクトルの分類は, 肺癌患者の治療方針の決定や予後の推測など, 臨床像の把握に若干でも役立つ適切な指標であ ろうと思われる。

\section{結 語}

肺癌患者58例について, 異ったタイプの免疫 能を反映していると考えられる 2 つの指標であ る, NK活性とDNCB反応を測定し, 両者の組合 わせによる免疫スペクトルを 4 群 $(\mathrm{A}, \mathrm{B}, \mathrm{C}$ ， D)に分け，その臨床的意義を検討した。
1. 肺癌患者は健常者にくらべ, NK活性, DNCB反応とも有意に低下していた。しかし， 両者間に相関はみられなかった。

2. 免疫スペクトルと臨床病態との関係では, 両者とも正常の A 群は, PSがよく, 遠隔転移が 少ないが，両者とも低下した D群では，PS，臨 床病期の進展した例が大部分を示した。どちら か一方が低下した $\mathrm{B} \cdot \mathrm{C}$ 群では，その中間の成 績が示された。免疫スペクトルと治療との関係 では，A群は $82 \%$ 高率で治療が期待できるが, $\mathrm{B} \cdot \mathrm{C}$ 群では約 $50 \%$ で, D群では全例が治療を 期待できなかった。

この新しい免疫スペクトルは, 肺癌患者につ いて，あらかじめ予後を予測することができ， 治療方針の決定に有用である。

本論文の要旨は, 第25回日本肺癌学会総会 (東京)で発 表した。
文

1) Forbes, J.T., Greco, F.A., Oldham, R.K. : Human natural cell-mediated cytotoxicity, II. Level in neoplastic disease. Cancer Immunol. Immunother. 11 : 147-153, 1981.

2) Takasugi, M., Ramseyer, A., Takasugi, J. : Decline of natural nonselective cell-mediated cytotoxicity in patients with tumor progression. Cancer Research 37:413-418, 1977.

3) Yasumoto, K., Ohta, M., Nomoto, K. : Cytotoxic activity of lymphocytes to bronchogenic carcinoma cells in patients with lung cancer. Gann 67 : 505-511, 1976.

4) 矢田健太郎：癌患者免疫能の診断パラメータ 一。 日内会誌。 67 : 1494-1499， 1978.

5）井上宏司, 石原恒夫, 菊地敬一, 他：DNCB反 応と肺癌患者の予後. 癌の臨床, $23: 1367-$ 1369, 1977.

6) Zubrod, C.G., Schneiderman, M., Frai, E., et al. : Appraisal of methods for the study of chemotherapy of cancer in man. J. Chron. Dis. 11: 7-33, 1960.
7) Vose, B.M., Moore, M.: Suppressor cell activity of lymphocyte infiltrating human lung and breast tumours. Int. J. Cancer 24 : 579-585, 1979.

8) Hochman, P.S., Cudkowicz, G. : Suppression of natural cytotoxicity by spleen cells of hydrocortison-treated mice. J. Immunol. 123 : 968-976, 1976.

9) Hudig, D., Haverty, T., Fulcher, C., et al.: Inhibition of human natural cytotoxicity by macro-molecular antiproteases. J. Immunol. 126: 1569-1574, 1981.

10) Nair, P.N.M., Fernandes, G., Onoue, K., et al.: Inhibition of effector cell function in natural killer cell activity (NK) and antibody-dependent cellulal cytotoxicity (ADCC) in mice by normal and cancer sera. Int. J. Cancer 25 : 667-677, 1980.

11）仙場敬三, 石谷邦彦, 漆崎一朗, 他：消化器癌 患者血清中のNK活性抑制因子. 消化器と免疫, $8: 245-248,1982$.

12) Liberati, A.M., Voelkel, J.G., Borden, E.C., et 
al.: Influence of non-specific immunologic factor on prognosis in advanced bronchogenic carcinoma. Cancer Immunor. Immunother. 13: 140-144, 1982.

13）西條長宏：人末梢血リンパ球Natural killer活 性の分析と原発性肺癌, 転移性肺腫瘍における 変動. 日癌治会誌, $15 ： 362-374,1980$.

14) Saijo, N., Shimizu, E., Shibuya, M., et al.: Effect of chemotherapy on natural killer activity and antibody-dependent cellmediated cytotoxicity in carcinoma of the lung. Br. J. Cancer 46: 180-189, 1982.

15) Saijo, N., Shimizu, E., Irimajiri, N., et al.: Analysis of natural killer activity and antibody-dependent cellullar cytotoxicity in healthy volunteers and in patients with primary lung cancer and metastatic pulmonary tumors. J. Cancer Res. Clin. Oncol. 102: 195-214, 1982.

16）宮本 宏, 井上勝一, 村尾 誠, 他: 肺癌患者 の遅延型皮虚過敏反応. 癌と化学療法, $5: 99-$ 108, 1978 .

17) Krant, M.J., Manskopf, G., Brandrup, C.S., et al. : Immunologic alteration in bronchogenic cancer. Cancer 21: 623-631, 1968.

18) Lee, Y.N., Sparks, F.C., Eilber, F.R., et al. : Delayed cutaneus hypersensitivity and peripheral lymphocyte counts in patients with advanced cancer. Cancer 35 : 748-755, 1975.

19) Gross, L.: Immunologic defect in aged population and its relationship to cancer. Cancer 18: 201-204, 1965.

20) Wardolf, D.S., Willkens, R.F., Deker, J.L. : Impaired delayed hypersensitivity in an agin- gpopulation. J.A.M.A. 203 : 831-834, 1968.

21) Golub, S.H., O'Connell, T.X., Morton, D.L., et al.: Correlation of in vitro assays of immunocompetence in cancer patients. Cancer Res. 34 : 1833-1837, 1974.

22) Lenzini, L., Rottoli, P., Rottoli, L.: The spectrum of human tuberculosis. Clin. exp. Immunol. 27 : 230-237, 1977.

23）三上理一郎：臨床免疫学的にみた結核発病の 要因. 結核, 59:39-63, 1984.

24) Yoneda, T., Mikami, R., Sakaguchi, Y., et al.: The immune spectrum in chronic, intracutable pulmonary tuberculosis. Brit. J. Dis. Chest Submitted to.

25）山口哲司, 小森吉晴, 村田修一, 他：肺癌免疫 化学療法の研究ーリンパ球幼若化反応の推 移一. 肺癌, $19: 331-334,1979$.

26) Lichtenstein, A., Zighelboim, J., Dorey, F., et al. : Comparison of immune drangements in patients with different malignancies. Cancer 45: 2090-2095, 1980.

27) Adler, A., Stein, J.A., Ben-Efrain, S.: Immunocompetence, immunosuppression, and human breast cancer. I. Prognostic significance of initial level of immunocompetence in early and advanced disease. Cancer 45 : 2074-2083, 1980.

28) Rasmussen, S.L., Gutterman, J.U., Hersh, E. M., et al. : BCG immunotherapy for recurrent malignant melanoma. A study of delayed hypersensitivity to recall antigens. Cancer Immunol. Immunother. 10: 17-26, 1980. 


\title{
The Immune Spectrum in Patients with Lung Cancer
}

\author{
Hiroshi Kitamura, Riichiro Mikami, Yasuhiro Sakaguchi, \\ Takahiro Yoneda, Hitoshi Katada, Junko Maekawa, \\ Kiyoshi Nishikawa and Nobuhiro Narita
}

The Second Department of Internal Medicine, Nara Medical University

The relationship between the immune responses and clinical manifestations in 58 patients with lung cancer was examined with a coordinated program of natural killer (NK) cell activity and delayed-type hypersensitivity reaction to dinitrochlorobenzene (DNCB).

Patients were divided into four groups : (A) normal NK cell activity ( $\geqq 25 \%)$ and positive reaction to $\mathrm{DNCB},(\mathrm{B})$ normal $\mathrm{NK}$ cell activity but negative reaction to $\mathrm{DNCB},(\mathrm{C})$ subnormal $\mathrm{NK}$ cell activity $(<25 \%)$ but positive reaction to $\mathrm{DNCB}$, (D) subnormal NK cell activity and negative reaction to $\mathrm{DNCB}$.

Group A patients were characterized by good performance status, low tumor burden and high response rate (82\%) to therapy, but group $\mathrm{D}$ patients were characterized by poor performance status, high tumor burden and no response to therapy. Group B and $\mathrm{C}$ patients showed intermediate patterns.

The immune spectrum presented here was shown to be related to the clinical manifestations. The simple method of immune spectrum evaluation might be a useful tool in the management of lung cancer patients. 